\title{
Effects of "Guie" on Soil Organic Carbon and Other Soil Properties: A Traditional Soil Fertility Management Practice in the Central Highlands of Ethiopia
}

\author{
Tadele Amare ${ }^{1,2}$, Birru Yitaferu ${ }^{1} \&$ Hans Hurni ${ }^{2}$ \\ ${ }^{1}$ Amhara Agricultural Research Institute (ARARI), Bahr Dar, Ethiopia \\ ${ }^{2}$ Centre for Development and Environment, Institute of Geography, Department of Integrative Geography, \\ Hallerstrasse 10, Bern CH-3012, Switzerland \\ Correspondence: Birru Yitaferu, Amhara Regional Agricultural Research Institute (ARARI), Bahir Dar, Ethiopia. \\ Tel: 251-58-220-5173. E-mail: birru_yitaferu2002@yahoo.com
}

Received: May 2, 2013 Accepted: June 4, 2013 Online Published: June 16, 2013

doi:10.5539/jas.v5n7p236

URL: http://dx.doi.org/10.5539/jas.v5n7p236

\begin{abstract}
A traditional soil fertility management practice through soil burning, locally called "guie" is practiced in the central highlands of Ethiopia. The study was conducted to investigate the effect of "guie" on physico-chemical properties of the soil and its long term impact on soil organic carbon (SOC). Two sets of soil samples were collected from the field. The first set was from central part of the heaps of the burnt soil. The second set was from adjacent cultivated fields used with and without "guie" for many years. Collected samples were analysed following standard laboratory procedures. Complete soil burning showed a significant decrease in SOC, total nitrogen, cation exchange capacity (CEC), exchangeable calcium, magnesium, sodium, available iron and clay while it significantly increased available phosphorus, manganese and copper, exchangeable potassium and sand. A significant difference $(\mathrm{p}<0.001)$ in SOC was also obtained for the second sample set. The highest $(7.14 \%)$ and the smallest (1.54\%) mean SOC was obtained from cultivated land where "guie" integrated with fallowing and without "guie" and fallowing, respectively. This indicates that fallowing could help the soil to accumulate SOC and if it coupled with the partial soil burning practice, accumulation of stable organic carbon in the soil could be enhanced. Intensive cultivation exposes the soil for erosion accompanied by active mineralization of the organic matter. Thus, results of the present study have an implication that fallowing integrated with "guie" is more sustainable to reserve $\mathrm{OC}$ in the soil system than the continuous cultivation.
\end{abstract}

Keywords: "guie", soil burning, SOC, Andit Tid, Ethiopian highland

\section{Introduction}

Ethiopia is one of the most populated countries in the Sub-Saharan Africa. Agriculture is the main stay for the majority of the society and contributes more than $40 \%$ of the GDP. The agricultural productivity has been heavily dependent on the natural fertility status of the soil. However, the natural potential of the soil to supply nutrients has been significantly reduced mainly due to erosion and depletion. The use of chemical fertilizers to improve the productivity of agriculture is limited because of the poor economic backgrounds of the vast majority of the society to afford the ever increasing cost of fertilizers. Therefore, efforts towards integrated soil fertility management practices may help to improve crop productivity that may lead to sustainable agriculture. For example long term investment on soil and water conservation (SWC) in the highlands of Ethiopia improved soil fertility (Adgo et al., 2013; Alemu et al., 2013; Amare et al., 2013). Ethiopian farmers also use various cultural soil fertility improvement practices such as inter cropping, crop rotation, fallowing and farmyard manure.

Farmers in the central highlands of Ethiopia have an old and a unique traditional soil fertility management practice through soil burning locally called "guie". Farmers use soil burning ("guie") to improve crop yield. For "guie" preparation, the land is left fallowed for more than 5 years. At the end of the fallow period, the land is ploughed shallowly $(\sim 10 \mathrm{~cm})$ in October while the soil is wet. Consequently, the soil gets dry and repeatedly ploughed so that clods of soil associated with a mass of roots (sods) separate easily from other parts of the soil. By collecting these sod associated soils, together heaps are made. With a size of about $80 \mathrm{~cm}$ in diameter and 60 $\mathrm{cm}$ in height around 900 heaps are made per hectare (Abebe, 1981). The heap is ignited by putting smaller dried 
cow dungs in the Centre of the heap as a starter and gradually the soil starts to burn by itself. This partial burning process that is similar to a traditional charcoal making, takes more than 15 days to complete the process. After the pyrolysis process completed, heaps of burned soil will be stayed as it is until the smaller rainy season starts in early March. As soon as the rainy season started, the heaps of burnt soil are distributed on the field and mixed by a repeated ploughing. Finally barley is grown without any chemical and other organic fertilizer sources.

Detail analysis of advantages and disadvantages of the soil burning ("guie") practice is important for setting alternative options. Fynn et al. (2003) reported about the significant reduction of soil organic carbon (SOC) due to long term effects of fire especially 0-2 cm soil layer in the grasslands of South Africa. Parlak (2011) reported that heating of the soil reduced the total nitrogen content and the cation exchange capacity while it increased available phosphorus, exchangeable potassium and the sand fraction. Ketterings et al. (2002) found an increase in the available phosphorus but for short time as sorption capacity of the soil was also increased by burning. Ketterings et al. (2000), Ketterings et al. (2002), Hubbert et al. (2006) and Parlak (2011) found a decreased in clay content by soil burning.

The main advantage of soil burning practice ("guie") in the heavy clay soils (vertisols) of Ethiopia is short term yield increase by improving mainly on the soil drainage (Abebe, 1981). However, in our study area, soil burning ("guie") is practiced in steep areas where drainage is not any more yield limiting. This indicates that detail analysis about advantage and disadvantage of this traditional soil fertility management needs to be carefully addressed. Understanding short and long term advantages as well as disadvantages of soil burning ("guie") which is unique and presently used in the Ethiopian highlands could help to substantiate the benefits of the existing practice and in case the practice damages the soil properties, this study could also help to design alternative and sustainable land management (SLM) practices. Therefore, the objectives of the research were:

- to investigate the effect of soil burning ("guie") on selected soil properties ,

- to investigate the long term impact of soil burning ("guie") on SOC.

\section{Materials and Methods}

\subsection{Description of the Study Area}

The study was carried out at Andit Tid watershed in the highlands of Ethiopia (Figure 1). It is located at $39^{\circ} 43^{\prime} \mathrm{E}$ and $9^{\circ} 48^{\prime} \mathrm{N}$ in North Shewa, Administrative Zone of the Amhara National Regional State. It has a catchment area of 477 hectares and it is in the Blue Nile Basin. The mean annual temperature and rainfall are $12.6^{\circ} \mathrm{C}$ and $1417 \mathrm{~mm}$ respectively. It has a bimodal type of rainfall. The altitude of the watershed ranges from 3040 to 3548 m.a.s.l. Geologically; the site is characterized by volcanic rocks such as rhyolites, trachites, tuffs and basalts (Brono \& Seiler, 1984). The major soils in Andit Tid watershed are: Andosol in the upper parts of the watershed, Fluvisol at the valley bottoms, Regosol at eroded parts and Liptosol on steep slope areas (Brono \& Seiler, 1984).

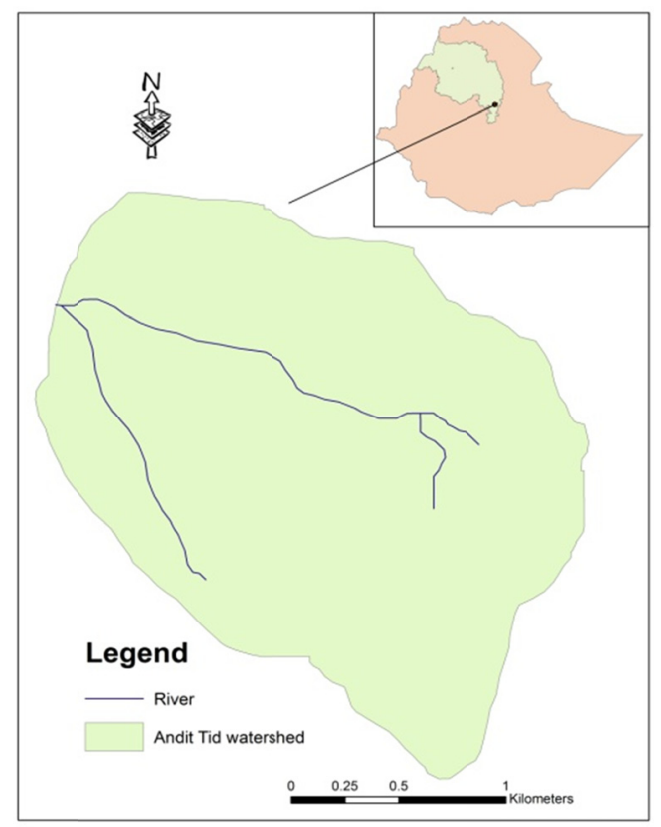

Figure 1. Location of Andit Tid watershed in the Amhara National Regional State of Ethiopia 


\subsection{Soil Sampling Strategy}

Two sets of soil samples were collected in April, 2012. The first set of soil samples include: 1) samples directly taken from central part of a burnt heap that were prepared by farmers for the upcoming cropping season, 2) from un-burnt soil associated with sods (mass of grass roots associated with the soil clods), and 3) from surface soil (0-10 cm depth) that were unburned and not associated with sods (Figure 2). Because farmers selectively use soil clods that are associated with a mass of roots developed in the course of fallowing period for "guie" making, we collected the soil clods from the same farm that were not burnt to compare with the burned ones. Samples from the soil clods associated with sods (here after called sod associated soil samples) throughout this paper. Similarly surface soil samples $(0-10 \mathrm{~cm})$ that were not burnt and were not associated with the sods were collected from the same farm. Soil samples were collected from five selected sites in the watershed where heaps of burnt soils were prepared and ready for use. For each site one composite sample was drawn from ten sampling points. With similar procedure and at the same site, composite samples were taken for the other two comparisons (2 and 3). The sites were considered as replications. Finally for the detailed analysis of physical and chemical properties of the soil, a total of 15 composite samples were taken: 5 from burned heaps, 5 from unburned soils associated with sods, and 5 surface samples that were not burned and not associated with the sod.

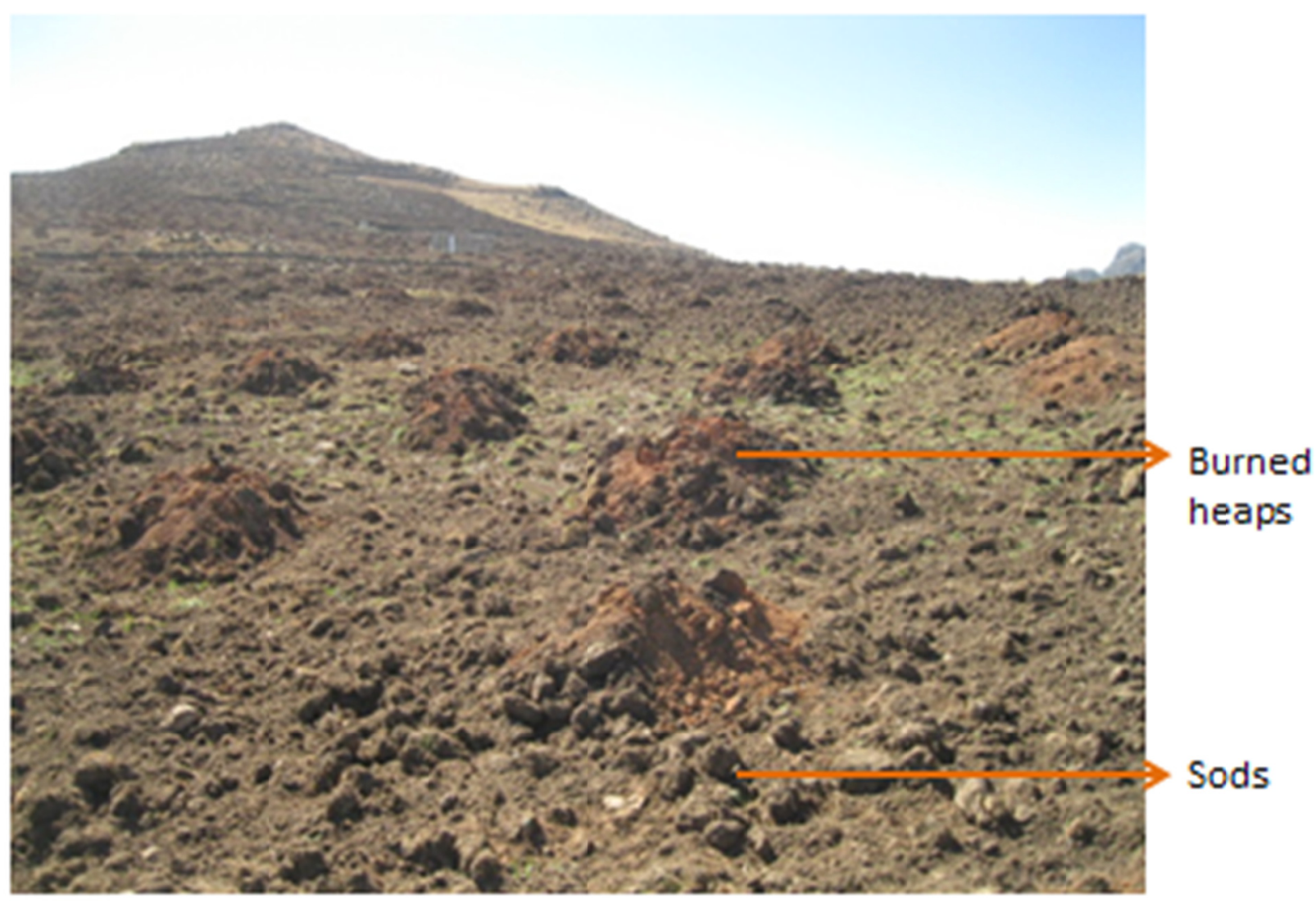

Figure 2. Heaps of soils under "guie" and unburned soil clods associated with sods (Photo by Tadele Amare,

March, 2012)

The second set of soil samples were collected from two adjacent cultivated fields where:

a. Soil burning with fallowing was used for many years,

b. Continuous cultivation without soil burning and without fallowing was used.

From the two fields a total of 69 soil samples: 48 from the first field and 21 from the second field were taken and compared the status of SOC. 


\subsection{Soil Preparations and Analysis}

The samples were air dried under shade, ground using pestle \& mortar and sieved to pass through $2 \mathrm{~mm}$ sieve. Soil $\mathrm{pH}$ was determined in a 1:2.5 soil to water suspension following the procedure outlined by Sertsu and Bekele (2000). The organic carbon content was determined by wet digestion method using the Walkley and Black procedure (Nelson \& Sommers, 1982). The total nitrogen content was determined using the Kjeldahl method (Bremner \& Mulvaney, 1982) while the available phosphorus was determined following the Olsen procedure (Olsen \& Sommer, 1982). The cation exchange capacity (CEC) was determined after extraction of the samples with $1 \mathrm{~N}$ ammonium acetate at $\mathrm{pH}-7$ and the aliquots were measured by atomic absorption for $\mathrm{Ca}^{2+}$, $\mathrm{Cu}^{2+}, \mathrm{Fe}^{2+}, \mathrm{Mg}^{2+}$ and $\mathrm{Mn}^{2+}$ while prepared aliquots were measured by flame photometer for the determination of $\mathrm{K}^{+}$and $\mathrm{Na}^{+}$following the procedures described by Sertsu and Bekele (2000). Soil texture was analysed using hydrometer method (Sertsu \& Bekele, 2000).

\subsection{Statistical Data Analysis}

The impact of independent variables such as soil burning on the dependent variables (soil properties) was statistically tested. Analysis of variance (ANOVA) was carried out using SAS 9.2 software (SAS, 2003). For variables showing statistically significant difference between treatments $(p<0.05)$, further analysis of mean separation was carried out using Duncan's Multiple Range Test (DMRT) at 5\% probability.

\section{Results and Discussions}

\subsection{Chemical and Physical Changes due to Soil Burning ("Guie")}

\subsubsection{SOC, Total Nitrogen and Available Phosphorus}

The effect of soil burning ("guie") that particularly changed into ash at the centre of the heap was recognized and resulted in a significant change on SOC, total nitrogen and available phosphorus of the soils. Particularly, the ash component is found to have very low in its SOC content and lower in total nitrogen. Compared to the mean SOC content of the surface soils, the ash component of the burnt heaps contained SOC that is as much as less than 1\% (Table 1). The difference in SOC content between burnt and un-burnt soil samples was highly significant $(\mathrm{p}<0.01)$. With high temperature, soil organic matter decomposed and changed into ashes. Similarly, Mataix-Solera et al. (2011) reviewed in detail that soil burning has a deleterious effect on SOC that results in deterioration of aggregate stability of the soil. Similarly, Sertsu \& Sánchez (1978) found that SOC was not affected at heating temperatures up to $200{ }^{\circ} \mathrm{C}$ while its effect is dramatic with the increasing temperature. According to their report, SOC was drastically reduced at temperatures above $200{ }^{\circ} \mathrm{C}$ and completely destroyed at $400{ }^{\circ} \mathrm{C}$. Finding the temperature equivalent to their findings $\left(200^{\circ} \mathrm{C}\right)$ at field conditions may help to obtain the positive contribution of soil burning with no or less destructive effects. On the other hand, burnt heaps have different intensity of burning forming clear layers with different effects on SOC (Wehrmann \& legesse, 1965 cited by Abebe, 1981). They identified a carbonized layer next to the layer where maximum burning temperature exerted (ash layer). According to the report, colour of the carbonized layer is black that might be associated with carbon trapped from the ash layer as well as partial decomposition of the soil organic matter (pyrolysis effect); this could help to store carbon for many years in the soil similar to biochar. However, our research was based on the ash part where complete burning is taking place in the profile of the heaps and hence limited for making a conclusive remark that "guie" has a disastrous effect on the long term SOC reserves.

The highest SOC (7.56\%) was obtained from un-burnt soil samples associated with sods followed by un-burnt surface soils $(7.17 \%)$. The higher SOC from un-burnt soils is associated with sods clearly demonstrates why farmers selectively use it for soil burning ("guie"). Similarly farmers use to plough only the topsoil $(<10 \mathrm{~cm})$ for the purpose of preparing the "guie", because high SOC at topsoil helps to burn the soil very easily.

Soil burning ("guie") also resulted in a highly significant $(\mathrm{p}<0.01 \%)$ decrease on total nitrogen content of the completely burned soils (Table 1$)$. The minimum value of total nitrogen $(0.11 \%)$ was obtained at the completely burnt soils, whereas the maximum value $(0.79 \%)$ was obtained at soil samples associated with un-burnt sods, indicating a significant amount of total nitrogen is contributed from the soil organic matter and sharply decreased upon breakdown of the organic matter due to ash making. Decreasing in total nitrogen does not reflect about the state of available nitrogen. For example Murphy et al. (2006) indicated that the concentration of available nitrogen both $\mathrm{NH}_{4}{ }^{+}$and $\mathrm{NO}_{3}{ }^{-}$increased in the soil solution after forest soil burning. Similarly, Sertsu and Sánchez (1978) reported that available nitrogen increased by soil burning at a temperature of $200^{\circ} \mathrm{C}$. 
Table 1. Effect of soil burning ("guie") on SOC, total nitrogen and available phosphorus

\begin{tabular}{llll}
\hline Treatment & SOC (\%) & Total nitrogen (\%) & Available-P (ppm) \\
\hline Burnt soil (heaps) & $0.95 \mathrm{~b}$ & $0.11 \mathrm{~b}$ & $50.2 \mathrm{~b}$ \\
Un-burnt soils associated with sods & $7.56 \mathrm{a}$ & $0.79 \mathrm{a}$ & $16.26 \mathrm{a}$ \\
Surface soil@ & $7.17 \mathrm{a}$ & $0.73 \mathrm{a}$ & $14.34 \mathrm{a}$ \\
Probability & $* *$ & $* *$ & $* *$
\end{tabular}

$\left.{ }^{(}\right)$Surface soil is soil sample that was collected at the depth of $0-10 \mathrm{~cm}$ but it was neither burnt nor associated with sods, ${ }^{* *}$ Significant at $\mathrm{p} \leq 0.01$.

The effect of soil burning on the availability of phosphorus was found significant. Available phosphorus from heaps of burnt soil was more than threefold ( $50.2 \mathrm{ppm})$ as compared to the un-burnt ones, whereby the difference was significant $(\mathrm{p}<0.01)$ as shown in Table 1 . The available phosphorus from soils associated with un-burnt sods was also found higher than un-burnt non-sod surface soil samples, which may be related with the soil organic matter and it is contributed majorly from organic phosphorus. The reasons for the increment of available phosphorus from burnt soil are: decomposition of soil organic matter helps to release phosphorus contained within it. Reduction of available iron by burning as shown in this research may also help to reduce fixation of phosphorus. The clay fraction was also found reduced due to soil burning, which improves phosphorus fixation. Abebe (1981) also indicated that soil burning reduces the exchangeable aluminium so that phosphorus fixation is reduced. Galang et al. (2010) found higher available phosphorus from a field after one week of prescribed burning. However, availability of phosphorus could be only for short time as other cations will come into solution due to soil burning and increase phosphorus fixation in turn. Additionally, the volume of the bunt soil (heaps) is very small compared to the un-burnt soil mass at the plough depth, thus its effect will be diluted and leading only short term availability of phosphorus as well as short term yield increment. Moreover, Ketterings et al. (2002) by heating the soil above $300{ }^{\circ} \mathrm{C}$ found an increase in surface area of minerals that increases phosphorus fixation. Therefore the state of heat induced availability of phosphorus may not be any more sustainable. That is why an extended fallowing period has been required after one cropping with soil burning.

Under laboratory condition, Sertsu and Sánchez (1978) found an increase in available phosphorus on the Ethiopian highland soils by heating the soils with temperatures ranging from 26 to $400{ }^{\circ} \mathrm{C}$. However, it was drastically decreased above $400{ }^{\circ} \mathrm{C}$. Interestingly, their result shows that available phosphorus was increased from less than $1 \mathrm{ppm}$ to greater than $30 \mathrm{ppm}$ by rising the heating temperature from 26 to $200{ }^{\circ} \mathrm{C}$ without a pronounced deleterious effect on other soil properties. By modifying farmers' soil burning practice to about 200 ${ }^{\circ} \mathrm{C}$ at field condition, equivalent crop yields to that of complete soil burning may be achieved and stable SOC can be accumulated in the soil that may help improve the soil health and other ecosystem and climate related functions.

\subsubsection{Soil pH, CEC, Exchangeable Bases and Micronutrients}

The effect of soil burning ("guie") on $\mathrm{pH}, \mathrm{CEC}$, exchangeable bases and available micro nutrients was found significant (Table 2). Its effect on $\mathrm{pH}$ was significant $(\mathrm{p}<0.01)$. It changed the soil $\mathrm{pH}$ from less than 5.7 to more than neutral. An increase in $\mathrm{pH}$ by soil burning could be due to the increase of cations in the soil solution. The difference in $\mathrm{pH}$ between un-burnt soil samples was insignificant. The value of $\mathrm{pH}$ obtained in this research is an ideal range for most cultivated crops. However, this value may be diluted upon applying to the field because its smaller volume compared to the volume of un-burnt soil masses.

The effect of soil burning on ("guie") CEC was strong and negative. CEC from burnt samples was less than by three fold from un-burnt soil samples (Table 2). Decrease in CEC due to soil burning could be related to a decrease in organic compounds and clay content. Because soil organic compounds and clay are the dominant sources for negative electrical charges that absorb the cations. Our finding is in line with the results of Marwa et al. (2009), and Sertsu and Sánchez (1978). 
Table 2. Effect of soil burning ("guie") on pH, CEC, Exchangeable bases and micronutrients

\begin{tabular}{|c|c|c|c|c|c|c|c|c|c|}
\hline \multirow[b]{2}{*}{ Treatment } & \multirow[b]{2}{*}{$\mathrm{pH}$} & \multirow[b]{2}{*}{ CEC } & \multicolumn{2}{|c|}{$\begin{array}{l}\text { Exchangeable } \\
(+) / \mathrm{kg})\end{array}$} & \multirow{2}{*}{$\begin{array}{r}\text { bases } \\
\mathrm{Mg} \\
\end{array}$} & \multirow{2}{*}{$\begin{array}{l}\text { (cmolec } \\
\mathrm{Na}\end{array}$} & \multicolumn{2}{|c|}{$\begin{array}{l}\text { Available } \\
(\mathrm{mg} / \mathrm{Kg})\end{array}$} & micro-nutrients \\
\hline & & & $\mathrm{K}$ & $\mathrm{Ca}$ & & & $\mathrm{Mn}$ & $\mathrm{Cu}$ & $\mathrm{Fe}$ \\
\hline Burnt soil & $7.25^{\mathrm{a}}$ & $23.14^{b}$ & $0.80^{\mathrm{a}}$ & $20.64^{b}$ & $2.07^{\mathrm{a}}$ & $0.66^{\mathrm{b}}$ & $41.45^{\mathrm{a}}$ & $0.36^{\mathrm{a}}$ & $30.09^{\mathrm{a}}$ \\
\hline $\begin{array}{l}\text { Soil associated with } \\
\text { sod }\end{array}$ & $5.64^{\mathrm{b}}$ & $63.81^{\mathrm{a}}$ & $0.71^{\mathrm{a}}$ & $33.29^{\mathrm{a}}$ & $2.31^{\mathrm{a}}$ & $0.96^{\mathrm{a}}$ & $18.11^{\mathrm{b}}$ & $0.12^{\mathrm{b}}$ & $37.26^{\mathrm{a}}$ \\
\hline Surface soil ${ }^{@}$ & $5.38^{\mathrm{b}}$ & $61.74^{\mathrm{a}}$ & $0.69^{\mathrm{a}}$ & $33.57^{\mathrm{a}}$ & $1.83^{\mathrm{a}}$ & $0.93^{\mathrm{a}}$ & $13.35^{\mathrm{b}}$ & $0.08^{\mathrm{b}}$ & $34.49 \mathrm{a}$ \\
\hline Probability & $* *$ & $* *$ & NS & $* *$ & NS & $* *$ & $* *$ & $* *$ & NS \\
\hline
\end{tabular}

(@) surface soil is soil sample that was collected at the depth of $0-10 \mathrm{~cm}$ but it was not burnt and it was not associated with sods, ${ }^{* *}$ significant at $\mathrm{p} \leq 0.01$, and NS is non-significant at $\mathrm{p} \leq 0.05$.

Exchangeable bases were affected by soil burning ("guie"). Exchangeable potassium was insignificantly increased by soil burning to about $0.10 \mathrm{cmole}(+) / \mathrm{kg}$ soil (Table 2$)$. Its increment from burnt soil may be related to the breakdown of minerals that leads to interlayer potassium cations conversion to exchangeable form. Marwa et al. (2009) reported that the possibility of potassium ion to be fixed by a hexagonal silicate layer is very low as compared to other interlayer cations. On other hand exchangeable $\mathrm{Ca}^{2+}, \mathrm{Mg}^{2+}$ and $\mathrm{Na}^{+}$were significantly decreased by burning; this could be because of these cations were changed to other oxides. Our finding is in line with the findings of Marwa et al. (2009) where they accounted the decrease in the exchangeable $\mathrm{Ca}^{2+}, \mathrm{Mg}^{2+}$ and $\mathrm{Na}^{+}$because of fixation by the hexagonal silicate layer.

The effect of soil burning ("guie") was significant on the availability of soil micro-nutrients (Table 2). Cu and Mn were increased significantly on the burnt soils while iron was insignificantly decreased. The availability of micronutrients was increased due to decomposition of organic compounds. Our finding with $\mathrm{Mn}$ and $\mathrm{Fe}$ availability agrees with the findings of Garcia-Marco and Gonzalez-Prieto (2008).

\subsubsection{Soil Texture}

Soil burning resulted in a change in soil texture (Table 3). The percentage of clay was significantly reduced whereas sand was increased by burning the soil. The finding, with regard to the decrease in clay content due to burning, is in agreement with the report by Abebe (1981), Urlery and Graham (1993), Ketterings et al. (2000), Ketterings et al. (2002), Hubbert et al. (2006), Parlak (2011), but it contradicts with the finding of Stoof et al. (2010). According to Verma and Jayakumar (2012), change in clay fraction to sand sized particle starts at about $400{ }^{\circ} \mathrm{C}$ where clay hydration and clay lattice structure start to collapse. Abebe (1981), Urlery and Graham (1993) suggested that soil burning resulted in a change in texture size from clay to sand by fusion of clay particles into sand size. Additionally, Urlery and Graham (1993) suggested that silicon and aluminium oxides and hydroxides released by decomposition used for cementing the clay particles into sand sized particles.

Table 3. Effect of soil burning ("guie") on the soil texture (\%)

\begin{tabular}{llll}
\hline Treatment & Clay & Sand & Silt \\
\hline Burnt soil & $16.96^{\mathrm{b}}$ & $38.06^{\mathrm{a}}$ & $44.98^{\mathrm{a}}$ \\
Soil associated with sod & $23.76^{\mathrm{a}}$ & $29.66^{\mathrm{a}}$ & $46.58^{\mathrm{a}}$ \\
Surface soil@ & $22.16^{\mathrm{a}}$ & $32.46^{\mathrm{a}}$ & $45.38^{\mathrm{a}}$ \\
Probability & $*$ & NS & NS
\end{tabular}

(a) Soil samples $(0-10 \mathrm{~cm})$ that are not burnt and not having sods, * significant at $\mathrm{p} \leq 0.05$, whereas NS is non-significant.

\subsection{Long Term Impacts of Soil Burning "Guie" on SOC}

Fields where soil burning with alternative fallowing has been exercised for long years were compared to adjacent cultivated field where soil burning has never been exercised. The difference in SOC between these two fields was highly significant $(\mathrm{p}<0.001)$ (Table 4$)$. The long term effects of removing and burning surface soils combined with long years of fallowing did not bring a deleterious effect upon SOC. On the contrary the SOC was found extremely low at the adjacent cultivated field where there is no fallowing and no soil burning 
practices. Two major factors may be accounted for the variations of the SOC under the two studied fields: first, the long years of strict fallowing produces large amount biomass production and part of it transferred to SOC. If this practice is accompanied by "guie" (a pyrolysis process), there could be biochar accumulation a stable carbon against decomposition. However, if there is a regulated "guie" process (a strict pyrolysis); in addition to the improvement in soil structures and nutrient availability, fallowing accompanied by "guie" can be equivalent to biocharing soils for better SOC accumulation in the soil system. The second reason may be related to their differences in the state of soil erosion for the two adjacent fields. Better vegetation cover due to fallowing helps to control soil erosion in the case of the first field, whereas the second field has been intensively cultivated without fallowing that exposes the soil for severe runoff erosion. Based on the results of these field comparisons, soil erosion can have a substantial effect on the removal of SOC with the surface soil. Moreover, the smaller fraction of burned soil applied in the field as compared to the larger volume of non-burnt soil may dilute the negative effects of soil burning on SOC.

Table 4. SOC (\%) in the cultivated fields with and without soil burning in Andit Tid watershed

\begin{tabular}{lllll}
\hline Sampling fields & \multicolumn{3}{l}{ Soil depth $(\mathrm{cm})$} & \\
\cline { 2 - 5 } & $0-10$ & $10-20$ & $20-30$ & Mean \\
\hline $\begin{array}{l}\text { Long years of soil burning integrated with } \\
\text { fallowing }(48)^{\dagger}\end{array}$ & $7.49^{\mathrm{a}}$ & $7.16^{\mathrm{a}}$ & $6.78^{\mathrm{a}}$ & $7.14^{\mathrm{a}}$ \\
$\begin{array}{l}\text { Continuous cultivation without soil burning and } \\
\text { without fallowing }(21)^{\dagger}\end{array}$ & $1.59^{\mathrm{b}}$ & $1.64^{\mathrm{b}}$ & $1.40^{\mathrm{b}}$ & $1.54^{\mathrm{b}}$ \\
\begin{tabular}{l} 
Probability \\
\hline
\end{tabular} & $* *$ & $* *$ & $* *$ & $* *$ \\
\hline
\end{tabular}

$\dagger$ numbers in bracket are the number of soil samples that were taken from the specified field, ${ }^{*}$ significant at $\mathrm{p} \leq 0.01$.

Wehrmann and Legesse (1965 cited by Abebe, 1981) indicated that burnt heaps have different layers including the carbonization layer where the colour of the soil is completely black may be due to partial decomposition of soil organic matter in this layer as well as carbon trapped from the completely burned layer (inner most layer where the layer dominated by ash). Application of this partially decomposed and trapped carbon may help to store more organic carbon in the soil system for longer time without decomposition, which may act similar functions to Biochar. However, this particular subject needs a detail research to identify the components of the SOC whether it is from the char or from the organic residues.

We compared also SOC obtained from the cultivated field where soil burning ("guie") integrated with fallowing with that of the adjacent forest and grass lands (Figure 3). SOC from cultivated land was found significantly lower than forest and grasslands at all depths. This also indicated that cultivation is still disastrous on the SOC reserves even under fallowing integrated "guie" system as compared to the forest and grass lands.

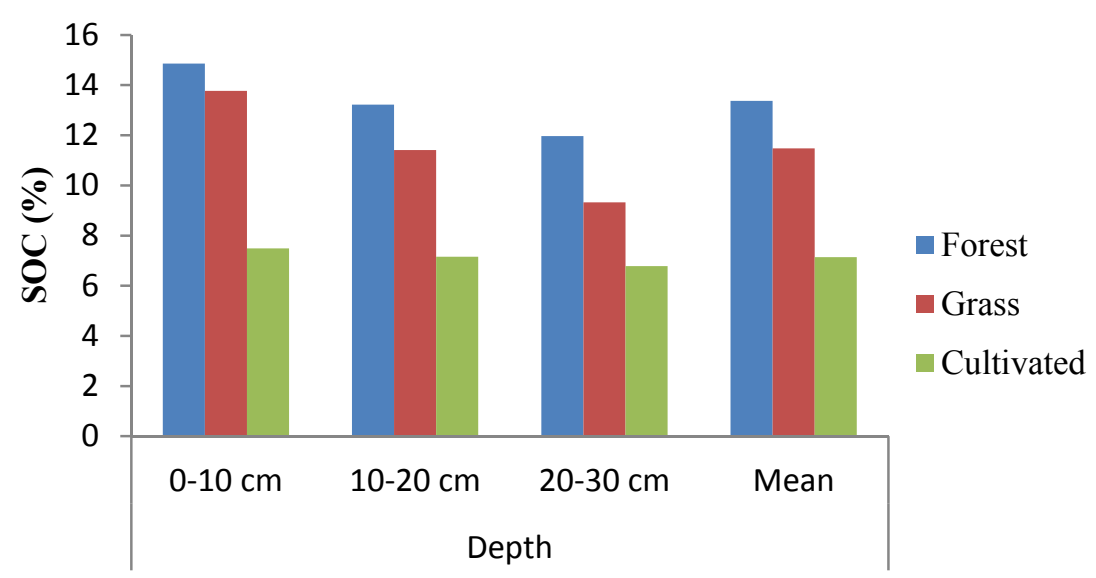

Figure 3. SOC as a fuction of different land uses. The forest and grass areas have never been changed to any landuse types in the last several decades and they are found adjacent to the cultivated field where long years of soil burning integrated with fallowing have been used 


\section{Conclusion and Recommendation}

The effects of soil burning or "guie" on soil physical and chemical properties and its long term impact on SOC in was investigated in Andit Tid watershed, Central Highlands of Ethiopia, where the system is currently practiced. The finding of the research showed that unregulated soil burning could reduce the SOC, total nitrogen, CEC, exchangeable bases and the clay content. On the other hand, availability of phosphorus, sand and availability of micronutrients increased. Availability of plant nutrients especially phosphorus is the main yield limiting factors in the study area and upon soil burning its availability was increased. The current practice of the farmers on "guie" that is integrated with fallowing showed high SOC (7.14\%) compared to adjacent fields $(1.54 \%)$ with intensive cultivation without fallowing and "guie". The deleterious effect of soil burning on SOC was not observed in the field as evidenced by this study. The partial burning effect that leaves chars in the soil would accumulate SOC over years. This could also be due to poor vegetation cover that usually accompanied by a severe soil erosion and poor organic return to the soil with continuous cultivation. Of course, the continuous cultivation can hasten microbial decomposition of soil organic matter that reduces the residence time of SOC in the soil system. Thus, results of the present study have an implication that fallowing integrated with "guie" is more sustainable to reserve OC in the soil system than the continuous cultivation.

Further research interventions are important on the residence time of the SOC by fallowing without soil burning, enhancing the biomass production through improved fallowing, and effect of soil burning on soil microorganisms. Moreover, determining the optimum temperature at which availability of plant nutrients such as phosphorus is increased with minimum destruction of other soil parameters including the SOC are critically important.

\section{Acknowledgements}

This paper is based on the work conducted within the framework of the Swiss National centre of Competence in Research (NCCR) North-South: Research Partnerships for Mitigating Syndromes of Global Change. We thank the Amhara Agricultural Research Institute (ARARI) for all supports and facilitations provided during the course of the study. We also thank the farmers in the study areas for their understanding while we were taking soil samples from their farms.

\section{References}

Abebe, M. (1981). Soil burning in Ethiopia. Ethiopian Journal of Agricultural Sciences, III(1), 57-74.

Adgo, E., Teshome, A., \& Matid, B. (2013). Impacts of long-term soil and water conservation on agricultural productivity: The case of Anjeni watershed, Ethiopia. Agricultural Water Management, 117, 55-61. http://dx.doi.org/10.1016/j.agwat.2012.10.026.

Alemu, W., Amare, T., Yitaferu, B., G. Selassie, Y., Wolfgramm, B., \& Hurni, H. (2013). Impacts of Soil and Water Conservation on Land Suitability to Crops: The Case of Anjeni Watershed, Northwest Ethiopia. Journal of Agricultural Science, 5(2), 95-109. http://dx.doi.org/10.5539/jas.v5n2p95

Amare, T., Terefe, A., G. Selassie, Y., Yitaferu, B., Wolfgramm, B., \& Hurni, H. (2013). Soil properties and crop yields along the terraces and toposequece of Anjeni Watershed, central highlands of Ethiopia. Journal of Agricultural Science: 5(2), 134-144. http://dx.doi.org/10.5539/jas.v5n2p134

Bremner, J. M., \& Mulvaney, C. S. (1982). Nitrogen Total. In A. L. Page, R. H. Miller, \& D. R. Keeney (Eds.), Methods of Soil Analysis (vol. 2). Wisconsin: Madison.

Brono, R., \& Seiler, W. (1984). The soils of the Andit Tid Research Unit (Ethiopia). Classification, morphology and ecology with soil map 1: 10,000. Soil conservation research project. Research report 3, University of Bern, Switzerland.

Fynn, R. W. S., Haynes, R. J., \& O’Connor, T. G. (2003). Burning causes long-term changes in soil organic matter content of South African grassland. Soil Biology \& Biochemistry, 35(5), 677-687. http://dx.doi.org/10.1016/S0038-0717(03)00054-3

Galang, M. A., Markewitz, D., \& Morris, L. A. (2010). Soil phosphorus transformations under forest burning and laboratory heat treatments. Geoderma, 155, 401-408. http://dx.doi.org/10.1016/j.geoderma.2009.12.026

García-Marco, S., \& González-Prieto, S. (2008). Short and medium term effects of fire fighting chemicals on soil micronutrient availability. Science of the Total Environment, 407(1), 297-303. http://dx.doi.org/10.1016/j.scitotenv.2008.08.021.

Hubbert, K. R., Preisler, T. H. K., Wohlgemuth, P. M., Graham, R. C., \& Narog, M. G. (2006). Prescribed 
burning effects on soil physical properties and soil water repellency in a steep chaparral watershed, southern California, USA. Geoderma, 130(3-4), 284-298. http://dx.doi.org/10.1016/j.geoderma.2005.02.001

Ketterings, Q. M., Bigham, J. M., \& Laperche, V. (2000). Changes in soil mineralogy and texture caused by slash and burn fires in Sumatra, Indonesia. Soil Sci. Soc. Am. J., 64, 1108-1117. http://dx.doi.org/10.2136/sssaj2000.6431108x

Ketterings, Q. M., van Noordwijk, M., \& Bigham, J. M. (2002). Soil phosphorus availability after slash-and-burn fires of different intensities in rubber agro-forests in Sumatra, Indonesia. Agriculture, Ecosystems and Environment, 92(1), 37-48. http://dx.doi.org/10.1016/S0167-8809(01)00287-0

Marwa, E. M. M., Meharg, A. A., \& Rice, C. M. (2009). The effect of heating temperature on the properties of vermiculites from Tanzania with respect to potential agronomic applications. Applied Clay Science, 43(3-4), 376-382. http://dx.doi.org/10.1016/j.clay.2008.11.005.

Mataix-Solera, J., Cerdà, A., Arcenegui, V., Jordàn, A, \& Zavala, L. M. (2011). Fire effects on soil aggregation: A review. Earth-Science Reviews, 109(1-2), 44-60. http://dx.doi.org/10.1016/j.earscirev.2011.08.002.

Murphy, J. D., Johnson, D. W., Miller, W. W., Walkera, R. F., Carrolla, E. F., \& Blank, R. R. (2006). Wildfire effects on soil nutrients and leaching in a Tahoe Basin watershed. Journal of Environmental Quality, 35(2), 479-489. http://dx.doi.org/10.2134/jeq2005.0144

Nelson, D. W., \& Sommers, L. E. (1982). Total carbon, organic carbon and organic matter. In A. L. Page, R. H. Miller, \& D. R. Keeney (Ed.), Methods of soil analysis. Part 2: Chemical and microbiological properties. Wisconsin: Madison.

Olsen, S. R., \& Sommers, L. E. (1982). Phosphorus. In A. L. Page, R. H. Miller, \& D. R. Keeney (Ed.), Method of soil analysis. Part 2: Chemical and microbiological properties (pp. 403-430). Wisconsin: Madison.

Parlak, M. (2011). Effect of heating on some physical, chemical and mineralogical aspects of forest soil. Bartın Orman Fakültesi Dergisi, 13(19), 143-152. Retrieved from http://bof.bartin.edu.tr/journal/1302-0943/2011/Cilt13/Sayi19/2011-13.pdf

Sertsu, S., \& Sánchez, P. A. (1978). Effects of heating on some changes in soil properties in relation to an Ethiopian Land Management Practice. Soil Science society of America. Journal, 42, 940-944. http://dx.doi.org/10.2136/sssaj1978.03615995004200060023x

Sertsu, S., \& Bekele, T. (2000). Procedures for soil and plant analysis. Technical paper no. 74. National Soil Research Centre, Ethiopian Agricultural Research Organization, Addis Ababa, Ethiopia.

Statistical Analysis System (SAS). (2003). SAS Institute Inc., Statistical Analysis System, Cary, NC, USA.

Stoof, C. R., Wesseling, J. G., \& Ritsema, C. J. (2010). Effect of fire and ash on water retention. Geoderma, 3-4, http://dx.doi.org/10.16/j.geoderma.2010.08.002

Ulery, A. L. \& Graham, R. C. (1993). Forest fire effects on soil color and texture. Soil Science Society of America Journal, 57(1), 135-140. http://dx.doi.org/10.2136/sssaj1993.03615995005700010026x

Verma, S., \& Jayakumar, J. (2012). Impact of forest fire on physical, chemical and biological properties of soil: A review. Proceedings of international academy of ecology and environmental sciences, 2(3), 168-176.

\section{Copyrights}

Copyright for this article is retained by the author(s), with first publication rights granted to the journal.

This is an open-access article distributed under the terms and conditions of the Creative Commons Attribution license (http://creativecommons.org/licenses/by/3.0/). 